\title{
Successful resuscitation of serious bupivacaine intoxi- cation in a patient with pre-existing heart failure
}

\author{
[Réanimation réussie à la suite d'une intoxication sévère à la bupivacaïne chez \\ une patiente souffrant d'insuffisance cardiaque préexistante]
}

Jean-Christophe Favier MD, Manuel Da Conceiçao MD, Mikaïla Fassassi MD, Laurent Allanic MD, Thierry Steiner MD, Raphaël Pitti MD

Purpose: In dogs intoxicated with bupivacaine, clonidine is effective to treat conduction disturbances and dobutamine corrects myocardial depression. We report the case of a patient who experienced severe bupivacaine cardiotoxicity and who was treated successfully using these medications.

Clinical features: In a patient with pre-existing heart failure a surgical procedure to fix a humeral fracture was necessary. Preoperatively, heart failure was controlled with transcutaneous nitroglycerin and iv deslanoside. A bupivacaine bolus was administred iv accidentally (a mixture of bupivacaine $75 \mathrm{mg}$, I $5 \mu \mathrm{g}$ clonidine). The patient developped nodal rhythm with extreme bradycardia, severe shock and convulsions. Seizures were controlled with thiopentone/succinylcholine. Epinephrine iv boluses (0.1 $\mathrm{mg} \times 3$ ) restored blood pressure $(\mathrm{BP})$ to $50 / 30 \mathrm{mmHg}$ and heart rate $(H R)$ to 60 (nodal rhythm).

Following $75 \mu \mathrm{g}$ clonidine iv, BP rose to $90 / 70$ and HR to $90 \mathrm{~min}$. Cardiac rhythm reverted to sinus rhythm with first degree atrioventricular block. Echocardiography showed hyperkinesia and relative hypovolemia that was controlled with iv administration of terlipressin and glucagon. Subsequent dobutamine infusion stabilized hemodynamic conditions. It was decided to proceed with surgery using a midazolam/sufentanil based general anesthetic. In the intensive care unit, recovery, extubation and weaning from the dobutamine infusion were realized within $16 \mathrm{hr}$ of the event.

Conclusions: In this patient with preoperative heart failure, clonidine was effective to treat bupivacaine induced conduction disturbances. Epinephrine and dobutamine were effective to treat myocardial depression and terlipressin effectively controlled vasodilatation.
Objectif: Chez les chiens intoxiqués à la bupivacaïne, la clonidine est efficace pour traiter les troubles de conduction, et la dobutamine pour corriger la dépression myocardique. Nous présentons le cas d'une patiente qui a présentré une cardiotoxicité sévère à la bupivacaïne et qui a été traitée avec succès avec ces médicaments.

Éléments cliniques : Une patiente atteinte d'insuffisance cardiaque préexistante devait subir la réparation d'une fracture humérale. Avant l'opération, l'insuffisance cardiaque a été contrôlée avec de la trinitrine transcutanée et du deslanoside iv. Un bolus iv de bupivacaïne a été administré accidentellement (un mélange de 75 mg de bupivacaïne et de $15 \mu g$ de clonidine). Un rythme nodal s'est développé, accompagné d'une bradycardie extrême, d'un choc sévère et de convulsions. Les convulsions ont été maîtrisées par l'injection de thiopental/succinylcholine. Les bolus d'adrénaline iv $(0,1 \mathrm{mg} \times 3)$ ont ramené la tension artérielle (TA) à 50/30 $\mathrm{mmHg}$ et la fréquence cardiaque (FC) à 60 (rythme nodal). Après l'administration iv de $75 \mu \mathrm{g}$ de clonidine, la TA est passée à 90/70 et la FC à 90/min. Le rythme cardiaque est revenu à un rythme sinusal avec un bloc auriculo-ventriculaire du premier degré. L'échocardiographie a mis en évidence un état hyperkinétique et une hypovolémie relative qui ont été traitées par l'administration iv de terlipressine et de glucagon. Une perfusion ultérieure de dobutamine a permis de stabiliser les conditions hémodynamiques. L'opération a été réalisée sous anesthésie générale par midazolam/sufentanil. Dans l'unité de soins intensifs, le réveil, l'extubation et le sevrage de la perfusion de dobutamine ont été réalisés en moins de 16 h après la survenue de l'incident.

Conclusion : La clonidine a été efficace pour traiter les troubles de conduction induits par la bupivacaïne chez une patiente atteinte d'insuffisance cardiaque connue avant l'opération. L'adrénaline et la dobutamine ont permis de traiter la dépression myocardique et, la terlipressine, de contrôler la vasodilatation.

From the Intensive Care Unit, Hôpital Legouest, Metz Armées, France

Address correspondence to: Dr. Jean-Christophe Favier, service d'anesthésie, B.P. 10, Hôpital d'instruction des Armées Legouest, 57998

Metz Armées, France. Fax: 33 387564769; E-mail: legouest.daru@dial.oleane.com

Support was provided solely from institutional and/or departmental sources.

Accepted for publication May 23, 2002.

Revision accepted September 6, 2002. 


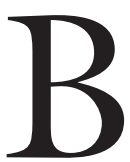
UPIVACAINE is cardiotoxic and treatment in the event of accidental overdosage remains problematic. ${ }^{1}$ We report a case of severe intoxication following the accidental $i v$ injection of bupivacaine.

\section{Case report}

A 60 -yr-old woman $(1.63 \mathrm{~m}, 58 \mathrm{~kg})$ was admitted to the general ward for a fracture of the distal humerus. The surgeon decided reduction and fixation were required urgently (fracture with vascular threat).

Her past medical history included angina (without myocardial infarction) leading to coronary bypass surgery in 1999 and hyperthyroidism with supraventricular rhythm disorder (tachysystole), treated three weeks before with radioactive iodine and beta blockers. Dosages realized on admission showed she was euthyroid.

On admission, her blood pressure (BP) was 110/70 $\mathrm{mmHg}$ and she was in sinus rhythm with a heart rate (HR) of $110 \mathrm{~min}^{-1}$. The patient showed signs of global heart failure: edema of the lower limbs, turgescence of the jugular veins with hepatojugular reflux, indicating right cardiac failure. Upon auscultation, a gallop rhythm (S3) was heard and (sub) crepitations were detected in the lung bases indicating left cardiac failure. The chest $x$-ray showed Kerley- B lines and a cardiomegaly with a cardiothoracic index of 0.6. $\mathrm{SpO}_{2}$ was $93 \%$ on air. No oxygen was delivered to the patient.

Prior to admission the patient was treated with: propranolol $160 \mathrm{mg} \cdot \mathrm{day}^{-1}$, molsidomine (a nitroglycerin equivalent): $6 \mathrm{mg} \cdot \mathrm{day}^{-1}$, lisinopril $10 \mathrm{mg} \cdot \mathrm{day}^{-1}$, furosemide $40 \mathrm{mg} \cdot \mathrm{day}^{-1}$, acenocoumarol $1 \mathrm{mg} \cdot \mathrm{day}^{-1}$, and potassium chloride $600 \mathrm{mg} \cdot \mathrm{day}^{-1}$. Beta-blockers had been maintained before admission even if there was no supraventricular rhythm disorder (the patient had not been reevaluated by the cardiologist). The patient took all her medications (including betablockers) before the accident.

Transthoracic echocardiography (TTE) showed a left ventricular ejection fraction (LVEF) of $25 \%$, a cardiac output $(\mathrm{CO})$ of $4.5 \mathrm{~L} \cdot \mathrm{min}^{-1}$ and a blood volume at the upper limit of normal: the inferior vena cava (IVC) was $23 \mathrm{~mm}$ (normal range 20-22 $\mathrm{mm}$ ) in diameter remaining mobile with breathing, sinus tachycardia $(H R=110)$ was not controlled by analgesia (propacetamol $2 \mathrm{~g}$ iv and morphine titrated to obtain a visual analogue scale pain score of 20/100 mm). Under TTE monitoring, HR was controlled by the administration of deslanoside $0.8 \mathrm{mg} i v$. Transcutaneous nitroglycerin was also applied (10 $\mathrm{mg} \cdot \mathrm{day}^{-1}$ ) for the treatment of heart failure. No other treatment was delivered to the patient (diuretics, etc.).
Subsequently, lung crepitations disappeared, $\mathrm{SpO}_{2}$ remained $96 \%$ (on air), $\mathrm{BP}$ was $110 / 70 \mathrm{mmHg}$, HR decreased to 90, the electrocardiogram (ECG) showed sinus rhythm with $\mathrm{HR}=90$ and $\mathrm{PR}$ interval $=$ 120 msec, a new TTE showed: $\mathrm{LVEF}=30 \%, \mathrm{CO}=$ $4.5 \mathrm{~L} \cdot \mathrm{min}^{-1}$, IVC diameter $=21 \mathrm{~mm}$. Since heart failure was controlled, we felt it was possible to proceed with surgery under general anesthesia.

In the operating room, a mixture of $75 \mathrm{mg}$ bupivacaine and $15 \mu \mathrm{g}$ clonidine [ $15 \mu \mathrm{g}$ clonidine added to a 20 - $\mathrm{mL}$ syringe of $0.375 \%$ bupivacaine (without epinephrine)] was injected intravenously accidentally in less than one minute. The bupivacaine mixture prepared for another patient was mistaken for the syringe $(20 \mathrm{~mL})$ containing the antibioprophylaxis.

Immediately after injection the patient developed a seizure lasting approximatively $20 \mathrm{sec}$, developed extreme bradycardia with nodal rhythm and BP was unmeasurable. Blood samples for the measurement of bupivacaine plasma concentration were obtained. Results are presented in the Figure.

Following $100 \mathrm{mg}$ thiopentone, the seizure stopped, $50 \mathrm{mg}$ succinylcholine were administered $i v$, and the patient was intubated and the lungs ventilated mechanically. Simultaneously, $0.1 \mathrm{mg} \times 3$ of epinephrine were administred $i v$, bringing the $\mathrm{BP}$ to $50 / 30$ $\mathrm{mmHg}$ and HR to 60 while nodal rhythm persisted. Atropine $^{2}$ was not used because the occurrence of bupivacaine overdose was obvious; BP was unmeasurable and epinephrine appeared more interesting to treat shock and bradycardia simultaneously.

Following $75 \mu \mathrm{g}$ clonidine $i v$ (without an associated fluid challenge), BP rose to $90 / 70 \mathrm{mmHg}$ and HR to $90 \mathrm{~min}^{-1}$. The ECG showed sinus rhythm with first degree atrio-ventricular (AV) block. TTE showed a CO of $6.5 \mathrm{~L} \cdot \mathrm{min}^{-1}$, a LVEF of $40 \%$ and a very mobile IVC (mean diameter $11 \mathrm{~mm}$ ), suggestive of hyperkinesia and relative hypovolemia (central venous pressure $=0 \mathrm{mmHg}$ is the admitted echography value for such a small and hypermobile IVC). ${ }^{3}$ The relative hypovolemia was secondary to vasoplegia and calculated systemic vascular resistance was 880 dynes $\cdot \mathrm{sec}^{-1} \cdot \mathrm{cm}^{-5}$. Transdermic nitroglycerin was discontinued to minimize vasoplegia and the cardiocirculatory condition was stabilized with $3 \mathrm{mg}$ terlipressin and $2 \mathrm{mg}$ glucagon boluses. Thereafter, the hemodynamic variables were as follows: $\mathrm{BP}=110 / 70 \mathrm{mmHg}$, $\mathrm{HR}=120$ in sinus rhythm with AV block $\mathrm{I}, \mathrm{CO}=5$ $\mathrm{L} \cdot \mathrm{min}^{-1}$ and IVC $22 \mathrm{~mm}$ in diameter.

A dobutamine infusion was then started (10 $\left.\mu \mathrm{g} \cdot \mathrm{kg}^{-1} \cdot \mathrm{min}^{-1}\right) 30 \mathrm{~min}$ after the event. Hemodynamic and TTE variables remained stable.

In the absence of a prolonged circulatory arrest 
(blood gases were normal one hour after the event), it was decided to proceed with surgery (open reduction and fixation) using a midazolam/sufentanil based general anesthetic.

Two polymorphous ventricular extrasystolic episodes with a large number of doublets were observed under general anesthesia. These two episodes were treated by the administration of $1.5 \mathrm{~g}$ of iv $\mathrm{MgSO}_{4}$ and $75 \mu \mathrm{g}$ iv clonidine during each episode, with no further complications.

Postoperatively, the patient was transferred to the intensive care unit (ICU) for recovery.

Hemodynamic stability allowed recovery, extubation and weaning from the dobutamine infusion within $16 \mathrm{hr}$ of the event.

The patient left the ICU on the third day with no neurological sequelae.

\section{Discussion}

This case report suggests a number of preliminary remarks: 1) the absolute necessity for careful labelling of syringes in order to avoid an injection which might have serious consequences. ${ }^{4}$ Another solution could be the use of specific syringe conditionning dedicated to local anesthetics (for example, $30 \mathrm{~mL}$ syringes); 2 ) the value of ultrasound monitoring in the operating theatre allowing immediate interpretation of a complex hemodynamic situation and the required adjustment of treatment.

This case report illustrates the interest of clonididine, associated with epinephrine at first and then with dobutamine, in the treatment of acute bupivacaine intoxication in the presence of cardio-circulatory insufficiency. ${ }^{1,5}$

\section{Neurotoxicity}

Bupivacaine overdosage induces neurological manifestations and, in particular, convulsions. These manifestations are the first to appear above a concentration of $1.6 \mu \mathrm{g} \cdot \mathrm{mL}^{-1}{ }^{6}$ These manifestations can be treated with thiopentone or midazolam. ${ }^{5}$ In France, the standard recommandation is to use a reasonable dose of thiopentone rather than diazepam or midazolam. ${ }^{7}$ Thiopentone has significant hemodynamic consequences but is much more rapidly effective than midazolam and even more so than diazepam. ${ }^{7}$

\section{Cardiotoxic manifestations}

With bupivacaine toxicity, there are very severe disturbances in conduction (both AV and intraventricular) and circulatory failure with myocardial depression. ${ }^{1,2,5,7}$ Beta blockade and angina are considered as aggravating factors. 5,7
The optimal treatment of the cardiotoxic manifestations remains controversial.

\section{Conduction disturbances}

De La Coussaye et al. consider that atropine could probably be used safely. In the anesthetized dog pretreated with atropine and intoxicated with bupivacaine, conduction disturbances are not more severe with or without atropine. ${ }^{2}$

Lacombe et al. indicate that isoproterenol corrects the electrophysiologic changes induced by bupivacaine in a rabbit heart model. ${ }^{8}$

De La Coussaye et al. have shown that clonidine reverses the electrophysiologic effects induced by high doses of bupivacaine in anesthetized dogs. ${ }^{1}$

\section{Circulatory failure}

Dobutamine corrects myocardial depression induced by bupivacaine and the combination of clonidine and dobutamine reverses electrophysiologic and hemodynamic effects induced by high doses of bupivacaine in dogs. ${ }^{l}$ Epinephrine corrects myocardial depression induced by bupivacaine ${ }^{9}$ but possibly induces cardiac arrhythmias. ${ }^{5}$

In clinical practice, another case report supports the use of clonidine to treat bupivacaine intoxication. ${ }^{5}$ In this report, the patient $(163 \mathrm{~cm} / 75 \mathrm{~kg}$ ) developed convulsions and ventricular arrhythmias (ventricular fibrillation/ventricular tachycardia/ventricular flutter) after the injection of $150 \mathrm{mg}$ bupivacaine (with $1 / 200000$ epinephrine) administred during a lumbar plexus block. Convulsions were controlled with thiopentone $350 \mathrm{mg}$ and midazolam $5 \mathrm{mg}$. Cardioversions were ineffective (15 shocks). Sinus rhythm was restored only after the administration of clonidine iv $(150 \mu \mathrm{g} \times 2)$. Epinephrine was used initially to correct shock during the first three hours. Dobutamine, in combination with norepinephrine was used subsequently. Thus, a clonidine/dobutamine or epinephrine combination appears very interesting to treat the cardiotoxic manifestations of bupivacaine intoxication.

In our observation, it should be noted that the plasma concentration of bupivacaine after $30 \mathrm{~min}$ (first dosage), is just above the toxic level of $1.6 \mu \mathrm{g} \cdot \mathrm{mL}^{-1} .6$ Normally, this value is consistent with convulsions but not cardiotoxicity. Considering the pre-existing cardiac status, the bupivacaine concentration may have been cardiotoxic. In addition, this patient was receiving beta blockers. Within the framework of a bupivacaine overdose, the effect of beta-blockers on the heart, (on conduction disturbances in particular) were possibly increased even if, in our observation, there was no evidence of pre-existing beta blocker over- 


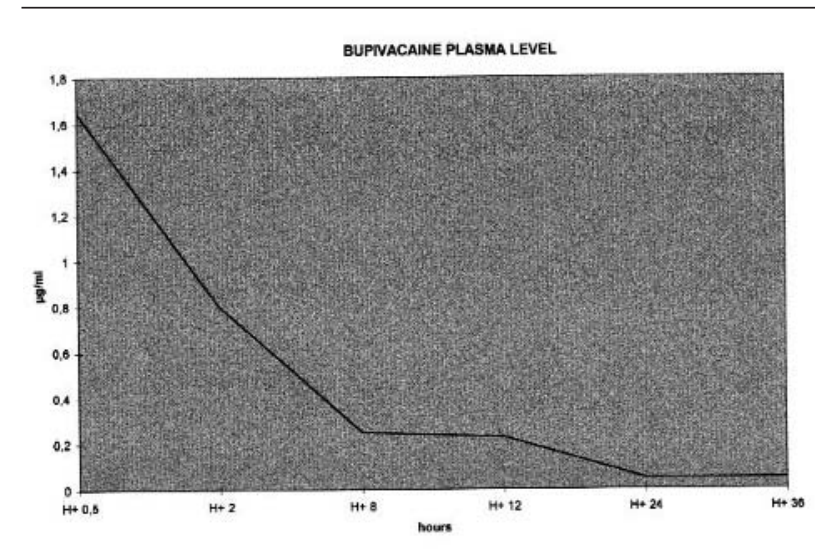

FIGURE Bupivacaine plasma concentrations. $\mathrm{H}$ denotes the time of accidental $i v$ injection of bupivacaine $(75 \mathrm{mg})+$ clonidine $(15 \mu \mathrm{g})$.

dosage. ${ }^{5}$ The use of glucagon is suggested for the treatment of intoxication with beta blockers. ${ }^{10}$ Since glucagon does not not cause changes in rhythm, this prompted us to use it. In retrospect, the use of glucagon may not have been justified but did not prove harmful.

The patient was receiving angiotensin-convertingenzyme-inhibitors (ACEI) with neutralization of the renin- angiotensin system for which terlipressin has been suggested as a treatment. ${ }^{11}$ During the initial stage, given the patient's critical condition the decision was taken to use glucagon jointly with terlipressin, without trying to distinguish their respective effects.

Clonidine has been proposed in the literature ${ }^{1,5}$ as an effective treatment of the AV conduction disturbances observed in bupivacaine intoxication. In our patient, clonidine was effective as a first-line treatment, but its hemodynamic effects (vasomotor paralysis) led us to use a vasoconstrictor known not to cause changes in rhythm (terlipressin). No adverse ischemic effects associated with terlipressin were observed in this patient with known coronary artery disease. Eyraud et al., ${ }^{11}$ have shown that terlipressin is effective to treat refractory hypotension occuring during general anesthesia, in patients treated with ACEI without impairing left ventricular function.

The addition of $15 \mu \mathrm{g}$ of clonidine in the local anesthetic syringe may have been helpful. On the over hand, this dose of clonidine is very low and cannot explain the initial cardiopulmonary collapse. The improvement secondary to the iv injection of $75 \mu \mathrm{g}$ clonidine was surprising because clonidine is only sup- posed to treat bupivacaine conduction disturbances. ${ }^{1}$ The absence of initial myocardial depression after the first $75 \mu \mathrm{g}$ iv dose is probably secondary to the previous use of epinephrine.

During the operation, disorders of ventricular rhythm were noted. The decision was taken to use two antiarythmic drugs: 1) an antiarrhythmic aimed at blocking a possible contribution of the digitalis glycoside: magnesium sulphate; ${ }^{12}$ 2) clonidine, on account of the proarrhythmic effects of bupivacaine.

The hemodynamic effects of bupivacaine and particularly its negative inotropic action, were prolonged, justifying the continued administration of dobutamine. In Pham-Dang's report, dobutamine was still necessary at $24 \mathrm{hr}^{5}$ but bupivacaine concentrations are not reported. In our observation, the serum level of bupivacaine was $0.23 \mu \mathrm{g} \cdot \mathrm{mL}^{-1}$ after $12 \mathrm{hr}$ (Figure), a level below the toxic threshold ${ }^{6}$ and there was no need to resort to clonidine again. Thus, our case report suggests that bupivacaine toxic levels are associated with cardiac status and patient medications. The occurrence of an AV block remains unexplained and the level of bupivacaine $36 \mathrm{hr}$ after the event $(0.05$ $\mu \mathrm{g} \cdot \mathrm{mL}^{-1}$ ) cannot account for this observation.

\section{Conclusion}

In this patient with preoperative heart failure, clonidine was effective to treat bupivacaine induced conduction disturbances. Epinephrine and dobutamine were effective to treat myocardial depression and terlipressin controlled vasodilatation.

\section{References}

1 de La Coussaye JE, Bassoul B, Brugada J, et al. Reversal of electrophysiologic and hemodynamic effects induced by high dose of bupivacaine by the combination of clonidine and dobutamine in anesthetized dogs. Anesth Analg 1992; 74: 703-11.

2 de La Coussaye JE, Eledjam JJ, Bruelle P, et al. Mechanisms of the putative cardioprotective effect of hexamethonium in anesthetized dogs given a large dose of bupivacaine. Anesthesiology 1994; 80: 595-605.

3 Mintz GS, Kotler MN, Parry WR, Iskandrian AS, Kane $S A$. Real-time inferior vena caval ultrasonography: normal and abnormal findings and its use in assessing right-heart function. Circulation 1981; 64: 1018-25.

4 Radhakrishna S. Syringe labels in anaesthetic induction rooms. Anaesthesia 1999; 54: 963-8.

5 Pham-Dang C, Beaumont S, Floch H, Bodin J, Winer A, Pinand $M$. Acute toxic accident following lumbar plexus block with bupivacaine (French). Ann Fr Anesth Réanim 2000; 19: 356-9. 
6 Reynolds F. Adverse effects of local anaesthetics. Br J Anaesth 1987; 59: 78-95.

7 Bruelle P, de La Coussaye JE, Eledjam JJ. Toxicité générale des anesthésiques locaux. In: Gosgnach $\mathrm{M}$, Chauvin M, Riou B (Eds.). Pharmacologie en Anesthésie-Réanimation. Paris: Arnette, 1998: 585-95.

8 Lacombe P, Blaise G, Hollmann C, Tanguay M, Loulmet $D$. Isoproterenol corrects the effects of bupivacaine on the electrophysiologic properties of the isolated rabbit heart. Anesth Analg 1991; 72: 70-4.

9 Moore DC, Scurlock JE. Possible role of epinephrine in prevention or correction of myocardial depression associated with bupivacaine. Anesth Analg 1983; 62: 450-3.

10 Firmin F, Metge I, Debru JL. Intoxication par les bêtabloquants. In: Danel V, Barriot P (Eds.). Les Intoxications Aiguës. Paris: Arnette, 1993: 407-19.

11 Eyraud D, Brabant S, Dieudonne N, et al. Treatment of intraoperative refractory hypotension with terlipressine in patients chronically treated with an antagonist of the renin-angiotensin system. Anesth Analg 1999; 88: 1-5.

12 Delhumeau A, Granry JC, Monrigal JP, Costerousse F. Therapeutic use of magnesium in anaesthesia and intensive care (French). Ann Fr Anesth Réanim 1995; 14: 406-16. 